\title{
Improved economic stimulation mechanism to reduce vehicle $\mathrm{CO}_{2}$ emissions
}

\author{
A. Golubeva \& E. Magaril \\ Department of Environmental Economics, \\ Ural Federal University, Russia
}

\begin{abstract}
One of the major problems associated with the negative environmental impact of vehicles is the significant level of $\mathrm{CO}_{2}$ emissions. The increasing concentration in $\mathrm{CO}_{2}$ in the atmosphere as a result of vehicle emissions is accompanied by both an increase in the consumption of petroleum fuels, which have limited resources, and global climate change. The aim of this work is to improve the mechanism of economic stimulation to reduce $\mathrm{CO}_{2}$ emissions from vehicles through changes in the system of taxation of oil products. Analytic investigation by the authors and the systematization of the main methods of reducing vehicle $\mathrm{CO}_{2}$ emissions have revealed the required government direction to improve the economic management of their implementation and the necessity for priority stimulation to produce and consume fuel that is more environmentally acceptable. One effective instrument for such stimulus is an improved method of taxing oil products through the introduction of a new tax which takes into account the level of $\mathrm{CO}_{2}$ emissions from fuel combustion while also taking state measures to limit the growth in prices for gasoline and diesel fuel. The authors have found the dependence of vehicle $\mathrm{CO}_{2}$ emissions on the qualitative characteristics of consumed fuel (gasoline and diesel) and have substantiated a methodological approach to the tax calculation.
\end{abstract}

Keywords: $\mathrm{CO}_{2}$ emission, economic stimulation, oil tax system, vehicle.

\section{Introduction}

Auto transport, which numbers over a billion units across the world, is one of the major consumers of oil products and, as a consequence, one of the utmost emitters of $\mathrm{CO}_{2}$. Consumption of fuel and energy resources is one of the main 
indicators of level of civilization. Rapidly developing economies require increasing the consumption of energy resources. In today's context of increasing natural resource scarcity and assimilating capacity of the environment, there is a strong need to elaborate and implement mechanisms for optimal use of the resources and to find the means to ensure sustainable, environmentally balanced economic development of the society, taking into consideration the interests of future generations. In this context, the search for new ways to reduce $\mathrm{CO}_{2}$ emission from vehicles in association with an increase in the consumption of scarce petroleum fuels is a topical problem.

According to assessment of the International Energy Agency [1] the priority direction of reducing of carbon dioxide emissions is an increase of vehicle's fuel efficiency, where the determining role belongs to fuel quality enhancement. The introduction of an effective economic stimulus for petroleum producers is one of the ways to resolve the problem.

\section{Vehicles as a $\mathrm{CO}_{2}$ emission source}

Auto transport consumes over 2 billion tons of motor fuel per year and their burning causes a big part of $\mathrm{CO}_{2}$ emission in atmosphere. In the structure of $\mathrm{CO}_{2}$ fuel combustion emissions in the world and in the Russian Federation the vehicles share is 16.4 and $8.8 \%$ respectively (table 1 ).

Table 1: $\quad \mathrm{CO}_{2}$ fuel combustion emissions in the world and in the Russian Federation sectors of the economy, 2010 [2].

\begin{tabular}{|c|c|c|c|c|c|}
\hline \multirow{2}{*}{ № } & Sector of the economy & \multicolumn{2}{|c|}{ In the world } & \multicolumn{2}{|c|}{ In the Russian Federation } \\
\cline { 3 - 6 } & $\begin{array}{c}\mathrm{CO}_{2} \\
\text { emission, } \\
\text { mln.t. }\end{array}$ & $\begin{array}{c}\text { Unit } \\
\text { weight, } \\
\%\end{array}$ & $\begin{array}{c}\mathrm{CO}_{2} \\
\text { emission, } \\
\text { mln.t. }\end{array}$ & $\begin{array}{c}\text { Unit } \\
\text { weight, \% }\end{array}$ \\
\hline 1 & Power industry & $12,480.6$ & 41.2 & 832.6 & 52.7 \\
\hline 2 & $\begin{array}{c}\text { Industrial production } \\
\text { and construction }\end{array}$ & $6,186.4$ & 20.4 & 294.3 & 18.6 \\
\hline 3 & Transport, including: & $6,755.8$ & 22.3 & 242.1 & 15.3 \\
\hline 3. & automobile transport & $4,972.1$ & 16.4 & 139.9 & 8.8 \\
\hline 1 & Other sectors & $1,570.8$ & 5.2 & 63.2 & 4.0 \\
\hline 5 & Other & $3,282.6$ & 10.8 & 149.2 & 9.4 \\
\hline & Total & $30,276.1$ & 100 & $1,581.4$ & 100.0 \\
\hline
\end{tabular}

Having calculated the contribution of the transport sector in the global $\mathrm{CO}_{2}$ emissions, the International Energy Agency has evaluated the share of transport in reduction of petroleum consumption in frame of the most optimistic of scenarios for accelerated technology development (Accelerated Technology scenarios) by 2050 is equal to $62 \%$ (Fig. 1) [1, 3].

It should be noted that the continuing rapid growth of the vehicle fleet alongside the almost unchanging quality of fuel consumed in Russia concurs with a proportional increase in $\mathrm{CO}_{2}$ auto transport emissions. 


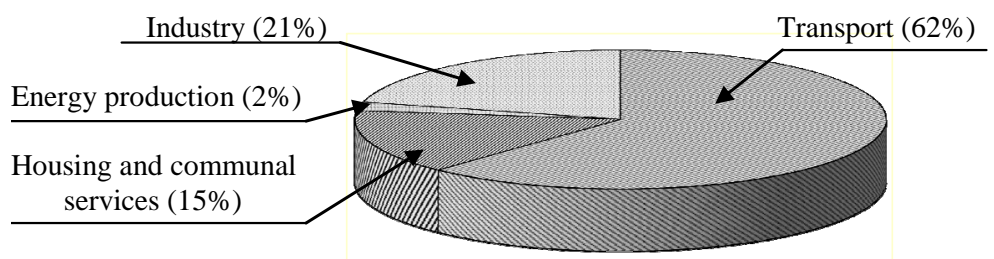

Figure 1: $\quad$ Reduction of oil consumption by the year 2050.

Table 2 shows data on vehicle fleet growth in Russia in the period from 2000 to 2011.

The results of negotiations among member countries of the UN Framework Convention on Climate Change which took place on Climate Change Conferences [4], economic mechanisms of the Kyoto Protocol and methodologies of greenhouse gases inventory [5-8] were analyzed. It led to the conclusion that nowadays the Kyoto Flexibility Mechanisms can be efficiently applied only to stationary sources of $\mathrm{CO}_{2}$ emissions (plants). It is difficult to obtain accurate data on emission produced by mobile sources, including vehicles, because of the difficulties in obtaining data for calculation. Hence, it is impossible to apply economic mechanisms of the Protocol effectively.

Table 2: $\quad$ Vehicle fleet dynamics in Russia, in thousands of units [9].

\begin{tabular}{|c|c|c|c|c|c|c|c|c|c|}
\hline \multirow{2}{*}{ № } & Item & \multicolumn{7}{|c|}{ Years } \\
\cline { 3 - 10 } & 2000 & 2005 & 2006 & 2007 & 2008 & 2009 & 2010 & 2011 \\
\hline 1 & $\begin{array}{l}\text { Motor } \\
\text { trucks }\end{array}$ & 4,401 & 4,848 & 4,929 & 5,168 & 5,349 & 5,323 & 5,414 & 5,545 \\
\hline 2 & Buses & 640 & 792 & 824 & 882 & 894 & 896 & 894 & 902 \\
\hline 3 & Cars & 20,353 & 25,570 & 26,794 & 29,405 & 32,021 & 33,084 & 34,354 & 36,415 \\
\hline & Total & 25,394 & 31,210 & 32,547 & 35,455 & 38,264 & 39,303 & 40,662 & 42,862 \\
\hline
\end{tabular}

It determines the need for substantiation of alternative mechanisms of reducing auto transport consumption of scarce hydrocarbon fuels.

\section{Means of reducing $\mathrm{CO}_{2}$ vehicle emissions}

In accordance with the optimistic scenario by the BLUE Map, the International Energy Agency estimated that by increasing fuel efficiency it is possible to reduce $74 \%$ of carbon dioxide emissions produced by the transport sector while another $26 \%$ can be reduced by the use of alternative fuels (Fig. 2) [1, 3]. 


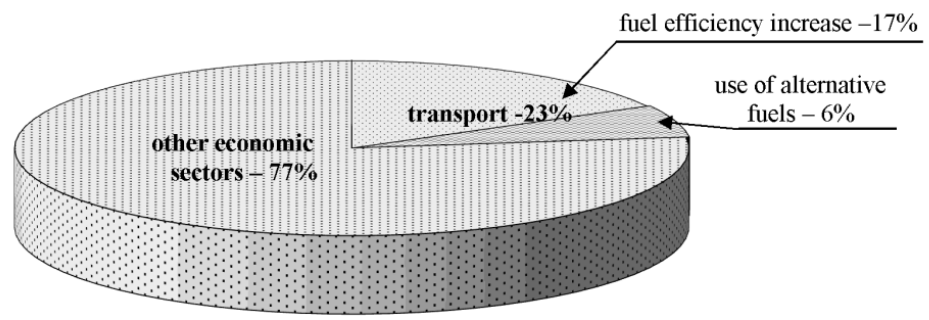

Figure 2: Share of transport in global $\mathrm{CO}_{2}$ emission reduction.

Figure 3 shows a systemized means of reducing $\mathrm{CO}_{2}$ vehicle emissions, which are divided into 2 groups. The first group is an increase of fuel efficiency of vehicles with gasoline and diesel engines. The second group is consumption of fuels and energy which are considered an alternative to traditional oil fuels (gasoline and diesel fuel) and energy.

\begin{tabular}{|c|c|}
\hline \multicolumn{2}{|c|}{ Means of reducing $\mathrm{CO}_{2}$ emissions } \\
\hline $\begin{array}{c}\text { The increase of fuel efficiency of } \\
\text { vehicles with gasoline and diesel } \\
\text { engines }\end{array}$ & $\begin{array}{c}\text { The use of alternative fuels } \\
\text { and energy }\end{array}$ \\
\hline $\begin{array}{c}\text { adherence to fuel saving driving } \\
\text { techniques }\end{array}$ & $\begin{array}{c}\text { compressed natural gas } \\
\text { (methane, ethane) }\end{array}$ \\
\hline $\begin{array}{c}\text { quality improvement of traditional } \\
\text { fuels }\end{array}$ & $\begin{array}{c}\text { liquefied petroleum gas (propane, } \\
\text { butane) }\end{array}$ \\
\hline $\begin{array}{c}\text { increase of a share of vehicles with } \\
\text { high fuel efficiency in the vehicle } \\
\text { fleet structure }\end{array}$ & $\begin{array}{c}\text { gasohol mixtures } \\
\text { (methanol, ethanol) }\end{array}$ \\
\hline $\begin{array}{c}\text { enhancement of a vehicle design } \\
\text { and construction of internal- } \\
\text { combustion engines }\end{array}$ & biodiesel \\
\hline \hline $\begin{array}{c}\text { enhancement of technical state of } \\
\text { transport }\end{array}$ \\
\hline \hline $\begin{array}{c}\text { hendrogen } \\
\text { enhancement of traffic organization }\end{array}$ \\
\hline
\end{tabular}

Figure 3: $\quad$ Means of reducing $\mathrm{CO}_{2}$ vehicle emissions.

It should be observed that among the discussed means of fuel efficiency increase in Russia the main one is the quality increase of gasoline and diesel 
fuels [10-12]. The analytical studies carried out by the authors revealed the main factors of fuel efficiency increase of automobile transport with gasoline and diesel engines (Fig.4).

The goal of $\mathrm{CO}_{2}$ emission reduction by vehicle fuel efficiency increase is one of the priorities for the international community, given the existing need for an efficient use of nonrenewable energy resources.

The systematization of revealed operational methods of $\mathrm{CO}_{2}$ transport emission reduction was made, which allowed us to determine instruments of reducing greenhouse gases transport emissions by implementing economic stimulation of parties involved in the transportation process. These instruments are alternative to those stated in the Kyoto Flexibility Mechanisms (table 3).

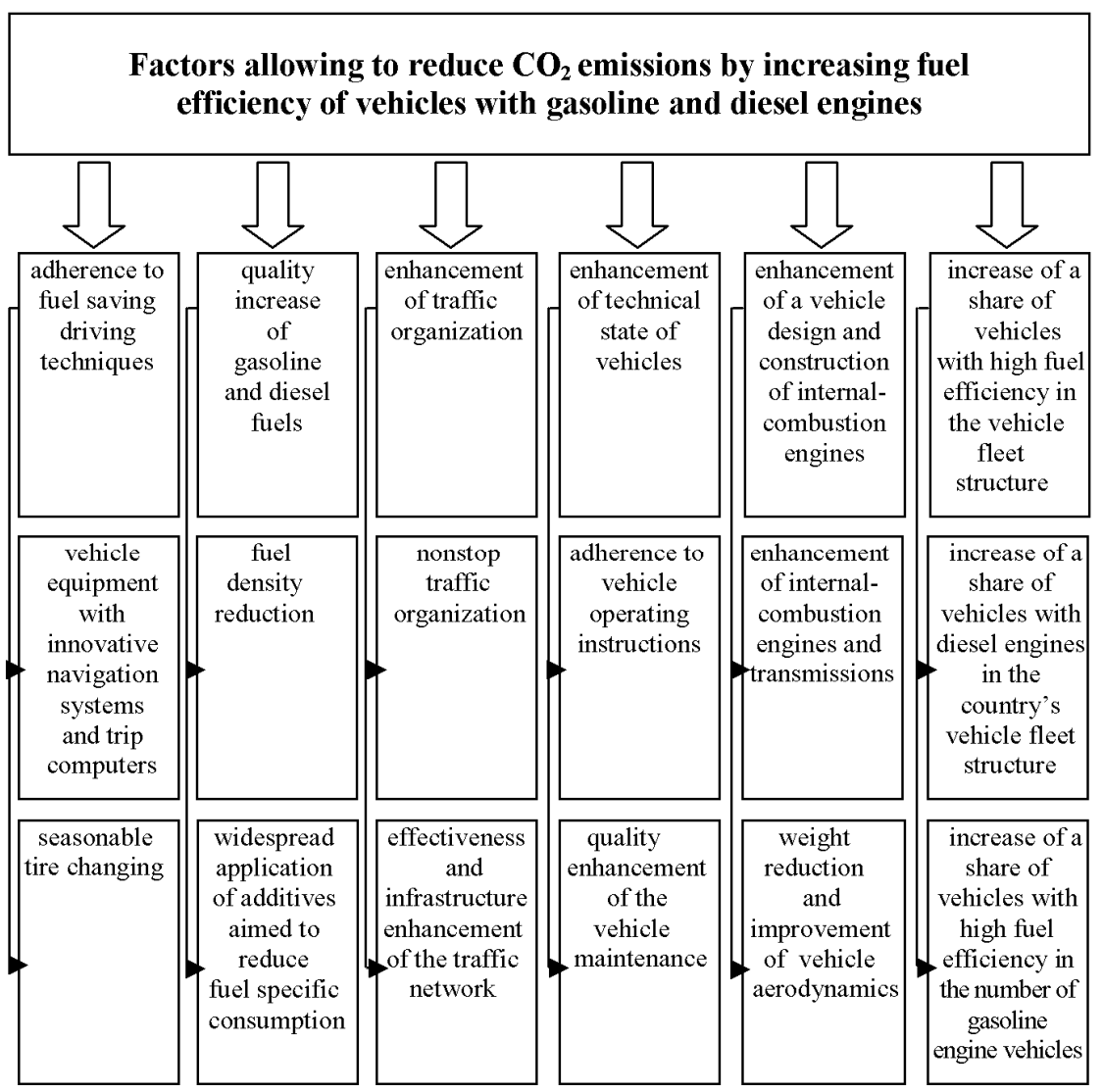

Figure 4: Factors allowing for reduction of $\mathrm{CO}_{2}$ emissions by increasing fuel efficiency. 
Table 3: Instruments of economic stimulation for reducing $\mathrm{CO}_{2}$ emissions towards responsible parties.

\begin{tabular}{|c|c|c|c|}
\hline Party & $\begin{array}{l}\text { Direction of } \\
\text { stimulation for } \\
\text { reducing } \mathrm{CO}_{2} \\
\text { emissions }\end{array}$ & Instrument & Remarks \\
\hline \multirow{9}{*}{ 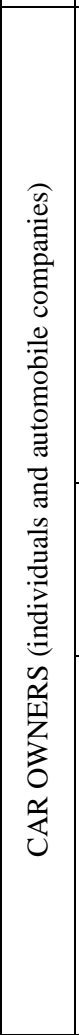 } & \multirow{4}{*}{$\begin{array}{l}\text { Stimulation of adherence } \\
\text { to fuel saving driving } \\
\text { techniques }\end{array}$} & $\begin{array}{l}\text { finance and } \\
\text { credit } \\
\text { mechanism }\end{array}$ & $\begin{array}{l}\text { introduction of fines for neglecting } \\
\text { the rules of seasonable tire change }\end{array}$ \\
\hline & & \multirow{2}{*}{$\begin{array}{l}\text { government } \\
\text { support }\end{array}$} & $\begin{array}{l}\text { financing of development and } \\
\text { introduction of new technologies in the } \\
\text { sphere of applying intelligence retrieval } \\
\text { systems and trip computers }\end{array}$ \\
\hline & & & $\begin{array}{l}\text { road network construction and } \\
\text { reconstruction of transportation systems } \\
\text { aimed to ensure nonstop traffic } \\
\text { organization }\end{array}$ \\
\hline & & $\begin{array}{l}\text { pricing } \\
\text { policy }\end{array}$ & $\begin{array}{l}\text { preferential pricing on innovative } \\
\text { navigation systems and trip computers }\end{array}$ \\
\hline & \multirow{2}{*}{$\begin{array}{l}\text { Stimulation of adherence } \\
\text { to vehicle operating } \\
\text { instructions }\end{array}$} & $\begin{array}{l}\text { finance and } \\
\text { credit } \\
\text { mechanism }\end{array}$ & $\begin{array}{l}\text { introduction of fines for undue vehicle } \\
\text { maintenance }\end{array}$ \\
\hline & & taxation & $\begin{array}{l}\text { graduated tax upon car owners } \\
\text { depending on vehicle operation life }\end{array}$ \\
\hline & \multirow{3}{*}{$\begin{array}{l}\text { Stimulation of purchase } \\
\text { of vehicles with high fuel } \\
\text { efficiency, among them } \\
\text { vehicles running on } \\
\text { alternative fuels and } \\
\text { energy }\end{array}$} & $\begin{array}{l}\text { government } \\
\text { support }\end{array}$ & old vehicles utilization program \\
\hline & & $\begin{array}{l}\text { pricing } \\
\text { policy }\end{array}$ & $\begin{array}{l}\text { preferential pricing on vehicles with } \\
\text { high fuel efficiency, among them } \\
\text { vehicles running on alternative fuels } \\
\text { and energy }\end{array}$ \\
\hline & & taxation & $\begin{array}{l}\text { preferential taxation for automobile } \\
\text { companies with high fuel efficiency } \\
\text { vehicles in the vehicle fleet structure, } \\
\text { among them vehicles running on } \\
\text { alternative fuels and energy }\end{array}$ \\
\hline \multirow{4}{*}{ 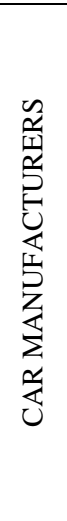 } & \multirow{2}{*}{$\begin{array}{l}\text { Stimulation of } \\
\text { development and } \\
\text { production of enhanced } \\
\text { internal-combustion } \\
\text { engines and vehicles with } \\
\text { advanced construction }\end{array}$} & $\begin{array}{l}\text { finance and } \\
\text { credit } \\
\text { mechanism }\end{array}$ & $\begin{array}{l}\text { preferential crediting of measures aimed } \\
\text { to develop technologies of enhancing } \\
\text { internal-combustion engines and vehicle } \\
\text { design, among them transition of } \\
\text { vehicles on alternative fuels and energy }\end{array}$ \\
\hline & & $\begin{array}{l}\text { government } \\
\text { support }\end{array}$ & $\begin{array}{l}\text { introduction of environmental subsidies } \\
\text { to developers and producers of high- } \\
\text { tech internal-combustion engines, } \\
\text { vehicle design allowing to increase fuel } \\
\text { efficiency, among them vehicles } \\
\text { running on alternative fuels and energy }\end{array}$ \\
\hline & \multirow{2}{*}{$\begin{array}{l}\text { Stimulation of keeping of } \\
\text { allowed } \mathrm{CO}_{2} \text { emissions } \\
\text { level for manufactured } \\
\text { vehicles }\end{array}$} & taxation & tax on vehicle $\mathrm{CO}_{2}$ emissions \\
\hline & & $\begin{array}{c}\text { environmental } \\
\text { certification } \\
\text { system }\end{array}$ & $\begin{array}{l}\text { enforcement of allowed } \mathrm{CO}_{2} \text { emissions } \\
\text { level on an average in a corporation/ } \\
\text { differentially on vehicles }\end{array}$ \\
\hline
\end{tabular}


Table 3: $\quad$ Continued.

\begin{tabular}{|c|c|c|c|}
\hline Party & $\begin{array}{c}\text { Direction of } \\
\text { stimulation for } \\
\text { reducing } \mathrm{CO}_{2} \text { emissions }\end{array}$ & Instrument & Remarks \\
\hline \multirow{9}{*}{ 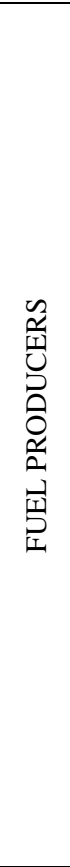 } & \multirow{5}{*}{$\begin{array}{l}\text { Stimulation of producing } \\
\text { fuels with lower } \mathrm{CO}_{2} \\
\text { emission level }\end{array}$} & $\begin{array}{l}\text { finance and } \\
\text { credit } \\
\text { mechanism }\end{array}$ & $\begin{array}{l}\text { preferential crediting of new refineries } \\
\text { construction }\end{array}$ \\
\hline & & $\begin{array}{l}\text { government } \\
\text { support }\end{array}$ & oil processing modernization \\
\hline & & $\begin{array}{l}\text { pricing } \\
\text { policy }\end{array}$ & $\begin{array}{l}\text { government limitation of price increase } \\
\text { on motor fuel }\end{array}$ \\
\hline & & taxation & $\begin{array}{l}\text { tax aimed to reduce } \mathrm{CO}_{2} \text { emissions } \\
\text { from fuel combustion }\end{array}$ \\
\hline & & $\begin{array}{l}\text { environmental } \\
\text { certification } \\
\text { system }\end{array}$ & $\begin{array}{l}\text { introduction of a index in fuel quality } \\
\text { certificates, indicating its } \mathrm{CO}_{2} \text { emission } \\
\text { level release while combustion (fuel } \\
\text { density can be taken as such index) }\end{array}$ \\
\hline & \multirow[t]{2}{*}{$\begin{array}{l}\text { Stimulation of alternative } \\
\text { fuels and energy } \\
\text { production }\end{array}$} & $\begin{array}{l}\text { finance and } \\
\text { credit } \\
\text { mechanism }\end{array}$ & $\begin{array}{l}\text { preferential crediting and investment } \\
\text { subventions for fuel producers } \\
\text { developing and producing alternative } \\
\text { fuels and energy }\end{array}$ \\
\hline & & $\begin{array}{l}\text { government } \\
\text { support }\end{array}$ & $\begin{array}{l}\text { support of development and production } \\
\text { of alternative fuels and energy }\end{array}$ \\
\hline & \multirow{2}{*}{$\begin{array}{l}\text { Stimulation of } \\
\text { application of additives } \\
\text { aimed to reduce fuel } \\
\text { specific consumption }\end{array}$} & $\begin{array}{l}\text { government } \\
\text { support }\end{array}$ & $\begin{array}{l}\text { support of developers and producers of } \\
\text { additives aimed to reduce fuel specific } \\
\text { consumption }\end{array}$ \\
\hline & & $\begin{array}{l}\text { environmental } \\
\text { certification } \\
\text { system }\end{array}$ & $\begin{array}{l}\text { prescribing an obligatory use of } \\
\text { additives in standards and technical } \\
\text { regulations }\end{array}$ \\
\hline
\end{tabular}

\section{Improvement of the oil products taxation system as a means of $\mathrm{CO}_{2}$ emission reduction}

\subsection{Substantiation of the need to levy a new oil products tax in Russia which is aimed at reducing $\mathrm{CO}_{2}$ emissions from fuel combustion}

The quality of Russian vehicle fuels is established in Technical Regulations on requirements for automotive and aviation gasoline, diesel and marine fuel, jet fuel and heating oil, approved by RF Government Decree № 118 of 27 February 2008 [13]. The Regulations contain the gradation of vehicle gasoline and diesel fuels incorporating four environmental categories that determine excise tax rates since 1 January 2011 [14]. The Regulations establish mandatory requirements to motor fuels, according to which "Euro-2" fuels shall be withdrawn from production starting from 1 January 2013, “Euro-3” fuels - from 1 January 2015, "Euro-3” fuels - from 1 January 2015 [13]. However, nowadays transition to the Technical Regulations requirements to fuel quality is substantially behind 
schedule. Russia's WTO entry will, to a certain extent, favor the more rapid modernization of oil processing in accordance with the government program.

Nowadays, the fiscal burden of Russia's oil industry is the heaviest in comparison to taxation systems in other oil producing countries. More than half of the national budget in Russia is formed by tax proceeds from the oil industry. The budget message set the task of improving taxation mechanisms in the sector to develop new deposits and, more importantly, to develop deep oil refining.

In Russia, taxes account for over $50 \%$ of the price of gasoline in comparison with gasoline prices in the US, where they depend mainly on the exchange quotations because the oil price makes up around $70 \%$ of the gasoline price. It has to be taken into consideration that in Russia, where the oil products' market is quite monopolistic, the price is determined, to a large extent, by arrangements set by the oil producers.

The enhancement of the oil taxation system along with taking contemporaneous measures of the government's limitations on oil prices can be an effective method of economic stimulation of environmentally friendly fuel production and consumption in the Russian Federation.

The main taxes which form a motor fuel price in Russia are the excise, the income tax, the value-added tax and the tax on mining operations. From all the taxes mentioned above only the excise depends on the motor fuel quality (from 1 January, 2011) because the existing rates depend directly on the environmental category of gasoline or diesel fuel. The analysis of the existing oil taxation system has shown that today's oil taxes in Russia, as well as in the rest of the world, are not connected with carbon dioxide emissions, therefore, they do not stimulate producers to reduce them. Although the excise existing in the Russian Federation depend on environmental characteristics of the fuel, they do not depend on the amount of $\mathrm{CO}_{2}$ emissions that are discharged in the burning process because fuels within a qualitative category can substantially differ in $\mathrm{CO}_{2}$ specific emission.

Taking into account that:

- the main $\mathrm{CO}_{2}$ emission source is fossil fuel combustion, one of the main consumers of which is automobile transport;

- $\quad$ one of the most effective instruments of pressure on the fuel producers is tax stimulation;

- $\quad$ fuel taxes nowadays do not depend on $\mathrm{CO}_{2}$ emissions,

It is necessary to improve the existing oil taxation system by introducing a new tax that would depend on $\mathrm{CO}_{2}$ emissions from fuel combustion. It is worth mentioning that introducing the new tax without government control over pricing, will lead to an increase in car fuel price and will stimulate consumers to buy fuel of higher quality instead of motivating producers to improve its quality.

\subsection{Methodological approach to calculating a tax depending on $\mathrm{CO}_{2}$ emission from fuel combustion}

The fuel quality and the $\mathrm{CO}_{2}$ emission from fuel combustion are, to a large extent, determined by fuel density which is an easily estimated and controlled 
indicator of quality of the oil product. Decrease in fuel density within a certain quality class does not require additional investments and is determined by the temperature range of grading gasoline and diesel content during the oil refining process $[10,11]$. Considering direct linear dependence of the $\mathrm{CO}_{2}$ emission from fuel density $[10,11]$, it is possible to introduce a tax on the motor fuel density which would supplement the existing taxation. This tax is reasonable to levy on produced fuels without taking into account the oil products which are the semiproducts for further processing of the fuel into commercial grade fuel. Thereby, the suggested tax on motor fuel density should be an indirect tax levied in addition to the excises on oil products.

The formula of calculating the tax on motor fuel density (1) is the following:

$$
\mathrm{T}=\mathrm{P}_{\mathrm{CO}_{2}} \cdot\left(G_{\mathrm{CO}_{2 i}}-G_{\mathrm{CO}_{2 i \min \rho}}\right)
$$

where $\mathrm{T}$ is a tax rate on motor fuel density; $P_{\mathrm{CO}_{2}}$ is the value of the $\mathrm{CO}_{2}$ emission quota on the global carbon market; $G_{\mathrm{CO}_{2}}$ is $\mathrm{CO}_{2}$ emission from combustion the i-type motor fuel (gasoline or diesel fuel) sold by the oil refiners, ton per fuel ton; $G_{\mathrm{CO}_{2} \text { min } \rho}$ is $\mathrm{CO}_{2}$ emission from combustion the i-type motor fuel (gasoline or diesel fuel) of minimum density, ton per fuel ton.

It should be mentioned that the suggested method of enhancing the oil product taxation system can be applied both in Russia and in other countries.

\section{Conclusion}

The enhancement of the existing world oil products' taxation systems by introducing a motor fuel density tax along with government measures aimed to limit the increase in prices will enable a decrease in the consumption of scarce hydrocarbon fuels, as well as reducing $\mathrm{CO}_{2}$ emissions from road transport and improving the environment in megalopolises.

\section{References}

[1] Energy Technology Perspectives. Scenarios and Strategies to 2050. International Energy Agency: Paris, 2006.

[2] $\mathrm{CO}_{2}$ Emissions from Fuel Combustion, 2012 Edition. IEA/OECD, 2012.

[3] Gusarov A.P. Fuel Consumption and Vehicle $\mathrm{CO}_{2}$ Emissions, http://www.aae-press.ru/j0056/art012.htm

[4] United Nations Framework Convention on Climate Change. FCCC/INFORMAL/84: United Nations, 1992.

[5] 2006 IPCC Guidelines for National Greenhouse Gas Inventories, Prepared by the National Greenhouse Gas Inventories Programme, Eggleston H.S., Buendia L., Miwa K., Ngara T. and Tanabe K. (eds). IGES: Japan, 2006.

[6] Revised 1996 IPCC Guidelines for National Greenhouse Gas Inventories: Reporting Instructions. IPCC, 1996. 
[7] Good Practice Guidance for Land Use, Land-Use Change and Forestry. Edited by Jim Penman, Michael Gytarsky, Taka Hiraishi, Thelma Krug, Dina Kruger, Riitta Pipatti, Leandro Buendia, Kyoko Miwa, Todd Ngara, Kiyoto Tanabe and Fabian Wagner. The Intergovernmental Panel on Climate Change (IPCC). IGES: Japan, 2003.

[8] Good Practice Guidance and Uncertainty Management in National Greenhouse Gas Inventories. IPCC, 2000.

[9] Federal state statistics service, http://www.gks.ru

[10] Magaril, E.R. Influence of the quality of engine fuels on the operation and environmental characteristics of vehicles: monograph [in Russian], Moscow: KDU, 2008.

[11] Magaril, E., Magaril R. Motor fuels: the problem of energy efficiency and environmental safety: monograph [in Russian], LAP LAMBERT Academic Publishing GmbH\& Co, Saarbrücken, Deutschland, 2012.

[12] Magaril, E. Improving car environmental and operational characteristics using a multifunctional fuel additive. Proc. of 19th Int. Conf. on Modelling, Monitoring and Management of Air Pollution, eds. C.A. Brebbia and J.W.S. Longhurst, WIT Press: Southampton, 2011.

[13] Technical Regulations on requirements for automotive and aviation gasoline, diesel and marine fuel, jet fuel and heating oil//Rossiyskaya Gazeta, issue № 47 (4604), 05.03.2008.

[14] Tax Code of the Russian Federation, http://base.consultant.ru/cons /cgi/online.cgi?req=doc;base $=\mathrm{LAW} ; \mathrm{n}=136059$ 